\title{
Characteristics of Congenital Heart of Premature Newborns
}

\section{Características das Cardiopatias Congênitas de Recém-Nascidos Prematuros}

\author{
Giuliana de Souza Sena*a; Sabrinne Suelen Santos Sampaio ${ }^{\mathrm{a}}$; Vanessa Braga Torres ${ }^{\mathrm{b}}$; Ingrid Guerra Azevedoc; \\ Nivia Maria Rodrigues Arrais ${ }^{\mathrm{b}}$ Ingrid Fonsêca Damasceno Bezerra ${ }^{\mathrm{a}}$; Silvana Alves Pereira ${ }^{\mathrm{d}}$ \\ ${ }^{a}$ Federal University of Rio Grande do Norte, Stricto Sensu Graduate Program in Physiotherapy,RN, Brazil. \\ ${ }^{b}$ Maternidade Escola Januário Cicco. RN, Brazil. \\ 'University Hospital Ana Bezerra, RN, Brazil.
}

${ }^{\mathrm{d}}$ Federal University of Rio Grande do Norte, School of Health Sciences of Trairi, Stricto Sensu Graduate Program in Rehabilitation Sciences and Collective Health, RN, Brazil.

*E-mail: giulianasena_29@hotmail.com

Recebido em: 19/02/19

Aprovado em: 05/08/19

\begin{abstract}
Congenital heart disease is considered the most common malformation found in neonatology. The aim of this study was to characterize the congenital heart diseases of premature newborns in the Neonatal Intensive Care Unit (NICU) of a high-risk maternity unit. This was an observational retrospective, descriptive character study carried out in a maternity school, reference in high-risk gestation in the state of Rio Grande do Norte. The study was carried out with premature infants admitted to NICU, who presented some cardiological findings when performing the echocardiogram examination. Data collection was performed through the records of infants hospitalized from December 2016 to December 2017. A total of 371 records were evaluated. Fifty-eight infants were diagnosed with congenital heart disease, and 38 of them had Persistence of the ductus arteriosus. The main diagnosed cardiopathies caused low pulmonary flow. About half of the pregnant women with cardiac infants presented some complications during pregnancy, and the most frequent was Urinary Tract Infection; 55 infants needed some ventilatory support, 14 had at least one extubation failure during the hospitalization period, and 8 presented atelectasis. Persistence of the ductus arteriosus was the most common cardiologic finding, and the most frequent congenital heart diseases were those that decreased pulmonary flow, diagnosed mostly in premature infants who needed some ventilation support, but who were discharged from hospital.
\end{abstract}

Keywords: Infant, Premature. Intensive Care Units, Neonatal. Neonatology.

\section{Resumo}

Cardiopatias congênitas (CC) são consideradas as malformações mais comuns encontradas na neonatologia. O objetivo deste estudo foi caracterizar as CC de recém-nascidos prematuros em Unidade de Terapia Intensiva Neonatal (UTIN) de uma maternidade de alto risco. Tratase de um estudo observacional retrospectivo, de caráter descritivo, realizado em uma maternidade escola, referência em gestação de alto risco do estado do Rio Grande do Norte. O estudo foi realizado com os bebês prematuros admitidos na UTIN, que apresentaram algum achado cardiológico ao realizar o exame de ecocardiograma. A coleta de dados foi realizada através dos prontuários dos bebês internados no período de dezembro de 2016 a dezembro de 2017. Foram avaliados 371 prontuários, sendo elencados para o estudo 58 bebês, 38 apresentaram persistência do canal arterial (PCA) e foram alocados no grupo PCA e 20 apresentaram outro tipo de CC e foram alocados no grupo CC. 55 bebês necessitaram do uso de algum suporte ventilatório, 14 apresentaram pelo menos uma falha de extubação durante o periodo de internação e 8 apresentaram atelectasia. Cerca de metade das gestantes com bebês cardiopatas apresentaram alguma intercorrência durante a gestação. A mais frequente foi à infecção do trato urinário. A PCA foi o achado cardiológico mais comum da amostra (65\%) e dentre os 20 RN com diferentes CC, as que causam o baixo fluxo pulmonar foram as mais frequentes (70\%), sendo encontradas em sua maioria em prematuros que necessitaram de algum suporte ventilatório, mas que receberam alta hospitalar.

Palavras-chave: Recém-Nascido Prematuro. Unidade de Terapia Intensiva Neonatal. Neonatologia.

\section{Introduction}

Congenital heart disease - CHD is considered the most common malformation found in neonatology. At birth, these infants have structural or functional abnormalities in the heart, which can lead to complications in the neonatal period ${ }^{2}$. These defects may decrease and increase the pulmonary flow and depend on the severity result in death, raising the rate of infant mortality, and making the disease an important public health problem $^{3}$.

Its prevalence continues to increase in the population and is one of the main causes of neonatal morbidity ${ }^{4}$. It is estimated that about $0.9 \%$ of live births are affected by some cardiopathy, and $20 \%$ to $30 \%$ occurs due to serious structural changes ${ }^{5}$. However, when considering the early and late fetal losses, the value of the incidence increases ${ }^{6}$. It is known that one third of deaths that occur between the twentieth week of pregnancy and the first year of life are due to a heart problem ${ }^{7}$.

It is believed that half of the CHD is presented in a benign form, which can be treated by available therapeutic and outpatient follow-up, and the other 50\% manifest in such a severe way, requiring more time consuming and complex treatment, and may evolve to severe sequelae and death ${ }^{7}$. 
Early diagnosis of this category of diseases is increasing, even in preterm infants ${ }^{5,8,9}$. This becomes even more worrying due to the risks caused by the immaturity of these babies.

The fact that several CHD evolve with cardiac insufficiency, early diagnosis is an important instrument for better clinical evolution and preventing further aggravation of these children ${ }^{10-12}$. The preventive measures are directed to an outlined profile, however there are few studies that present a profile of CHD in premature newborns. For that reason, the aim of this study was to characterize the CHD of premature newborns (PN) in the Neonatal Intensive Care Unit(NICU) of a high-risk maternity unit.

\section{Material and Methods}

This was an observational retrospective, descriptive character study carried out in the NICU of a maternity school, reference in high-risk gestation in the state of Rio Grande do Norte, composed of 23 beds. All preterm infants admitted to NICU and who presented some alteration in the echocardiogram were included. Those who presented as cardiac alteration abnormality the patent foramen ovale (PFO), those who closed in the neonatal period and the in PNs who had no cardiac abnormality, isolated pulmonary hypertension, heart valves without repercussion and those with persistent ductus arteriosus (PDA) by use of prostaglandin were excluded.

The research was carried out in the period from December 2016 to December 2017, through the Management Application for University Hospitals (AGHU), which corresponds to the system of maternity where the records of hospitalization of all patients are located from their entry until their leaving. A single researcher examined all the 371 records of PN

Initially the search was performed to identify those premature babies who presented some alteration in the echocardiogram, from then on, the researcher collected the data, the cardiac diagnosis, neonatal complications associated with heart disease, days of hospitalization, need for mechanical ventilation, quantity of planned and accidental extubation failure of extubation, days on oxygen therapy, need for sedation and vasoactive drugs, use of prostaglandin, use of ibuprofen, surgical indication and the outcome (discharge, transfer to another service or death).

The data analysis was performed using the Statistic Package for Social Sciences (SPSS), version 20.0. Descriptive evaluated variables were presented through measures of central tendency (median) and their measure of dispersion (quartile) and by means of relative and absolute frequencies. The Mann-Whitney test was used for comparison among the groups $(\mathrm{p}<0.05)$.

The study was submitted to the Committee for Ethics in Research in accordance with the notes of the Resolution $n^{\circ}$ 466/2012 of the National Health Council, receiving approval with the favorable opinion number 1.707.627. Anonymity and confidentiality were maintained, as well as all the ethical issues during the course of the research.

\section{Results and Discussion}

Of the 371 PNs admitted to NICU, 87 were premature infants who presented some cardiac findings on the echocardiogram and 58 comprised the sample. Figure 1 shows the flowchart.

Figure 1 - Flowchart of the sample.

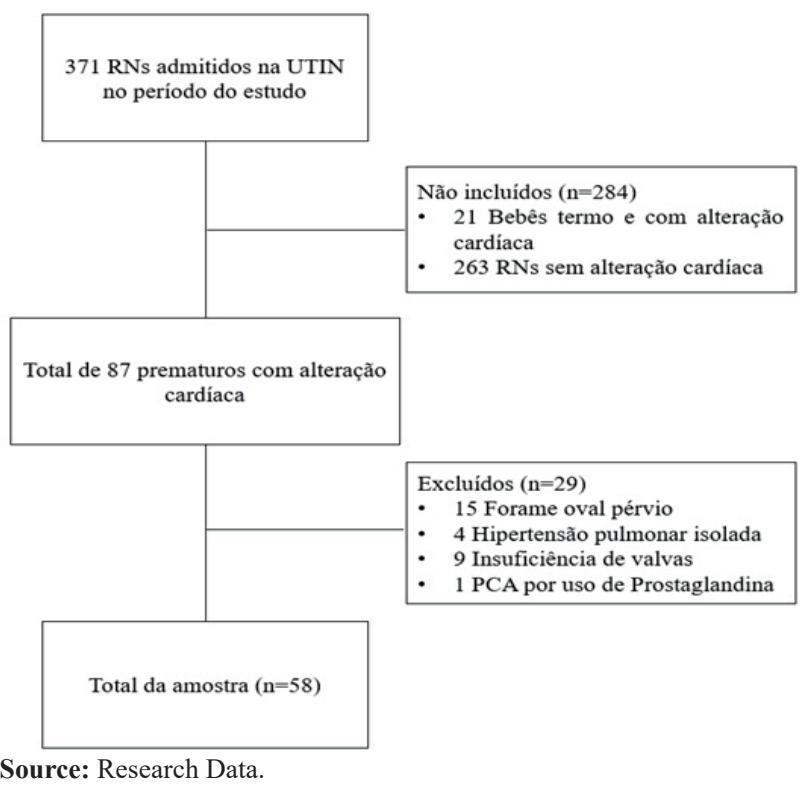

Of the 58 PNs with CHD, 38 (65\%) were diagnosed with PDA. Considering the PDS a common comorbidity to prematurity, it was opted to divide the sample into two groups: PDA- group of PNs with PDA diagnosis ( $\mathrm{n}=38$ ), and CC - group with other diagnosed cardiopathies $(n=20)$. The characteristics of the group with PDA will be presented in accordance with the amendment of pulmonary blood flow caused by the pathology. Table 1 presents the characteristics of the different groups.

Table 1 - Characterization of newborn infants during hospitalization

\begin{tabular}{|c|c|c|c|c|c|}
\hline \multirow{2}{*}{ Variables } & \multicolumn{2}{|c|}{ PDA $(n=38)$} & \multicolumn{2}{|c|}{ PN $(n=20)$} & \multirow[b]{2}{*}{$p$} \\
\hline & Median & Quartile & Median & Quartile & \\
\hline Mother's Age (years) & 25 & $21-32$ & 25 & $21-30$ & 0.93 \\
\hline IG (Weeks) & 28 & $26-31$ & 30 & $27-32$ & 0.17 \\
\hline Birth weight $(\mathrm{g})$ & 1,075 & $908.2-1,452.5$ & 1,370 & $1,008-1,744$ & 0.08 \\
\hline Apgar score at 1st minute & 6 & $4-9$ & 7 & $4-8$ & 0.89 \\
\hline Apgar score at 5 th minute & 8 & $7-9$ & 8 & $7-9$ & 0.99 \\
\hline Days of hospitalization & 44 & $21-62$ & 38 & $22-61$ & 0.79 \\
\hline Physiotherapy. & 35 & $16-79$ & 37 & $11-66$ & 0.45 \\
\hline Days of oxygen & 21 & $9-50$ & 17 & $5-32$ & 0.16 \\
\hline
\end{tabular}

PDA: Persistence of the ductus arteriosus; CHD: congenital heart defects; IG: Gestational age. ${ }^{*}$ The number of times that the patient underwent physiotherapy during hospitalization. 
Source: Research Data.

Of the 20 PNs in group CHD, $14(70 \%)$ had some CHD of low pulmonary flow. The most common diagnosis was pulmonary stenosis $n=12(60 \%)$. Table 2 presents the distribution of these heart diseases from the variation of pulmonary flow.

Table 2 - Description of heart diseases of group CHD from the variation of the pulmonary flow

\begin{tabular}{|c|c|c|}
\hline Diagnosis & n & \% \\
\hline Low pulmonary flow & 12 & $60 \%$ \\
\hline Pulmonary stenosis & 1 & $5 \%$ \\
\hline TGA & 1 & $5 \%$ \\
\hline Double outlet righ ventricle & 14 & $70 \%$ \\
\hline Total & 3 & $15 \%$ \\
\hline High pulmonary flow & 3 & $15 \%$ \\
\hline CIV & 6 & $30 \%$ \\
\hline
\end{tabular}

TGA Transposition of the great arteries; RV: Right ventricle; CIA: Atrial Septal Defect, CIV: Ventricular Septal Defect

Source: Research Data.

Just a baby of the group with CHD presented dependent cardiopathy of ductus arteriosus, requiring the use of prostaglandin, and 3 (15\%) underwent surgical indication. All the three PNs with surgical indication presented low pulmonary flow. In the PDA, 25 did not use pharmacological or surgical measure for closure of the ductus, 12 made use of ibuprofen, and only a baby received surgical indication.

Maternal characteristics and complications of the sample are described in Table 3.

Table 3 - Maternal characteristics of the sample.

\begin{tabular}{|c|c|c|c|c|}
\hline \multicolumn{3}{|c|}{ PDA $(n=38)$} & \multicolumn{2}{|c|}{ PN $(n=20)$} \\
\hline Variables & $\mathbf{n}$ & $\%$ & $\mathbf{n}$ & $\%$ \\
\hline \multicolumn{5}{|c|}{ Type of delivery } \\
\hline Vaginal & 18 & $47.4 \%$ & 7 & $35 \%$ \\
\hline Caesarian & 18 & $47.4 \%$ & 11 & $55 \%$ \\
\hline Not informed & 2 & $5.3 \%$ & 2 & $10 \%$ \\
\hline \multicolumn{5}{|c|}{ Complications in pregnancy } \\
\hline Yes & 20 & $52.6 \%$ & 10 & $50 \%$ \\
\hline No & 18 & $47.4 \%$ & 10 & $50 \%$ \\
\hline \multicolumn{5}{|l|}{ DHEG/HAS } \\
\hline Yes & 7 & $18.4 \%$ & 5 & $25 \%$ \\
\hline $\mathrm{No}$ & 31 & $81.6 \%$ & 15 & $75 \%$ \\
\hline \multicolumn{5}{|l|}{ DM } \\
\hline Yes & 2 & $5.3 \%$ & 2 & $10 \%$ \\
\hline No & 36 & $94.7 \%$ & 18 & $90 \%$ \\
\hline \multicolumn{5}{|l|}{ ITU } \\
\hline Yes & 13 & $34.2 \%$ & 6 & $30 \%$ \\
\hline $\mathrm{No}$ & 25 & $65.8 \%$ & 14 & $70 \%$ \\
\hline
\end{tabular}

PDA: Persistence of the ductus arteriosus; CHD: congenital heart defects; DHEG Specific hypertensive disease of pregnancy; DM: Diabetes mellitus; ITU: Urinary tract infection

Source: Research Data.

The main indication for NICU of the two groups was the presence of respiratory distress, in 16 infants $(42.1 \%)$ of the group with PDA and $12(60 \%)$ of the group of other CHDs. Almost the whole, $55(86.2 \%)$, required some ventilatory support, and of these, 36 presented the PDA and 14 of the group CHD presented low pulmonary flow.

The majority of the sample, $48(82.7 \%)$ used invasive mechanical ventilation (IMV) as ventilatory support, 32 of the group with PDA and 16 of the group with CHD; 11 with low pulmonary flow and 5 high flow.

Among the PSs who used VMI, 14 (29.1\%) had at least one of extubation failure during the hospitalization period, the majority $(n=9)$ was the group with PDA. On the remainder $(n=5)$ belonging to the group with the other PDA, 3 had low pulmonary flow and 2 high flow.

As associated complications, 8 (13.7\%) showed atelectasis in some period of hospitalization, and only 2 were from group CC, and both had high pulmonary flow. The six patients $(10.3 \%)$ who presented pulmonary hypertension were from group PDA.

In relation to the outcome of the sample, $38(65.5 \%)$ were discharged from the hospital. The majority $(n=25)$ belonged to the group PDA, of the 13 of the group CHD 9 had low pulmonary flow and 4 high flow. On transfers, 4 PNs (5.8\%) were transferred to another institution, 2 were from group PDA and 2 from Group CHD. Sixteen subjects (27.5\%) died, the majority $(n=11)$ of the group with PDA. And only 1 baby of the group CHD that presented a high pulmonary flow.

The data of this research show that $5.3 \%$ of 371 infants admitted to NICU were identified as premature infants with some cardiac malformation, being the most frequent PDA. And in the group of other CHDs, the pulmonary stenosis was the most found heart disease.

The description of CHD in preterm infants is still something little explored in the literature. Pérez et al. ${ }^{9}$, upon assessing the main causes of admission of 472 preterm infants in NICU, saw that $2.3 \%$ of the babies were referred with the diagnosis of CHD, in spite of not informing what is the most frequent heart disease.

The high prevalence of PDA was something expected in the case of a study with preterm infants. Other studies ${ }^{13,14}$ had already demonstrated that PDA is a common finding in newborns with less than 28 weeks.

Santos et al. ${ }^{15}$, in a study with 168 infants diagnosed with CHD met in a high-risk maternity, identified that $44.64 \%$ presented PDA. Among these, 112 were premature, being 64 with gestational age less than 30 weeks. Rivera et al. ${ }^{16}$ also showed a high incidence, $36 \%$ of PDA. Both studies justify their findings considering the prematurity of the sample.

The ductus arteriosus is a fetal communication that regularly closes at birth, in preterm infants, and with the increase in pulmonary resistance this channel remains patent, increasing the comorbidities during hospitalization ${ }^{17}$. In our sample, among the 38 patients diagnosed with PDA, 12 required the use of ibuprofen for closure of the channel, 
and only 1 had surgical indication. The 25 remaining cases underwent conservative treatment with indomethacin, because they had none or mild repercussion. Ibuprofen is a therapeutic alternative for the closure of PDA $^{18.19}$. In several controlled and randomized clinical trials, ibuprofen was as effective as indomethacin in the promotion of the closing of the canal, and had less effect on mesenteric, renal and cerebral perfusions ${ }^{18,20}$

In the group of other CHDs, those of low pulmonary flow were the most common, which may have contributed to a better prognosis for these babies, since the majority of the PNs of Group CHD who were discharged from the hospital $(n=9)$ presented low pulmonary flow. It is known that the pulmonary hyperflow often causes respiratory dysfunction in children with heart disease ${ }^{19}$ and this fact is even more worrying in newborn infants, due to pulmonary immaturity alone already generate serious consequences to the patient, which associated with pulmonary hyperflow may worsen the population in question ${ }^{20}$.

Unlike our study, some studies show the IVC as the most frequent malformation ${ }^{21}$. Aragon et al. ${ }^{21}$, upon examining the profile of 300 patients with heart disease, identified 63 diagnosed with IVC. However, the sample was composed by children of various ages, when almost half of the studied sample $(n=141)$ corresponded to infants, which differs from our study, that was carried out with newborn infants.

Cristovam et al. ${ }^{22}$ considered the heart murmur as the major cause of referral of these PNs to NICUS. However, this finding was present in less than half $(25.8 \%)$ of our sample, and it was the presence of respiratory distress the main indication for the babies' hospitalization. The pulmonary immaturity of this population hinders the gas exchange and makes the dyspnea the main sign in newborn infants after birth, which may justify our results ${ }^{20}$. Almost half of our sample needed the use of vasoactive drugs and the vast majority required the use of a ventilatory support, moreover, they had a prolonged hospitalization with excessive time in therapy.

Oxygen is the most commonly used therapy in neonatal care units as an integral part of the respiratory support ${ }^{23}$. Its goal is to achieve adequate oxygenation to the tissue without creating toxicity to the PN. However, recent studies have demonstrated that the oxygen supply has been greater than the need of the PN, and its deleterious effects has contributed to the maintenance of the subject inside the hospital ${ }^{24}$.

The most common pulmonary complication found in our study was atelectasis, with 4 cases in patients of group PDA and 4 in the group with the other CHD. These numbers were not highly discrepant from other studies ${ }^{25}$. In the study by Oliveira et al..$^{26}$ about the profile of children with heart disease undergoing surgery, $53 \%$ of the evaluated patients presented some postoperative complication, and the most frequent was the pleural effusion ( 8 cases), followed by atelectasis ( 6 cases).

Regarding the risk factors for the development of CHD, some authors show that infectious diseases during pregnancy may be related with cardiac abnormalities in the fetus ${ }^{4.5}$. Araújo and collaborators ${ }^{5}$ (2014) when registering the CHD in the state of Paraíba, saw that almost $50 \%$ of the sample were born to pregnant women who presented some acute disease during pregnancy.

Pinto et al. ${ }^{27}$ upon assessing the maternal risk factors associated with CHDsaw that $58 \%$ of the expectant mothers had some systemic disease prior to pregnancy, being ITU the most prevalent, with $52 \%$ of the cases. This percentage was followed by diabetes and/or hypertension, with $10 \%$ of the cases $^{27}$. These findings corroborate with our research, when approximately $50 \%$ of mothers had some complications during pregnancy, and ITU as the most frequent in both groups, both in the PDA and CHD. According to the Ministry of Health ${ }^{28}$, ITU is the most common urinary problem of gestation and is associated with premature rupture of membranes, triggering a premature birth, which could justify the prematurity of our newborns.

Studies show that the prematurity and birth weight seem to influence the mortality rate of children with heart disease ${ }^{21.29}$. Curzon et al. ${ }^{29}$ compared groups of children with birth weights above and below $2500 \mathrm{~g}$ and verified that the group of lower weight showed significantly greater difference in mortality. Andrews et al. ${ }^{30}$ reported a rate of $72 \%$ death rate in premature children with CHD upon evaluating the pregnancy and the evolution of babies. As our sample was composed by preterm infants, this fact may have influenced the mortality rate found, which was $27.5 \%$.

The largest part of the NICU prematures studied in this research corresponded to babies born by cesarean, diagnosed with PDA or with some other CHD with decreased pulmonary blood flow. This research was carried out at the maternity unit reference in high-risk pregnancies in the state of Rio Grande do Norte. In recent years, there have been changes in the team and the infrastructure of the sector, and today the unit benefits from the team of pediatric cardiology and a greater number of beds, which contributed to the georeferencing of cardiac PNs. However, this contribution is recent, and the organization of medical records is still incipient. In this way, it is intended to follow with the continuation of this study so that we can get even more relevant data on diseases in the population of preterm infants.

\section{Conclusion}

PDA and the pulmonary stenosis were the most common cardiological findings among the studied preterm infants. The heart disease of -low pulmonary flow was diagnosed in its majority in preterm infants who needed some ventilatory support but had as outcome the hospital discharge.

\section{References}

1. Liang Q, Gong W, Zheng D, Zhong R, Wen Y, Wang X. The influence of maternal exposure history to virus and medicine during pregnancy on congenital heart defects of 
fetus. Environ Sci Pollut Res 2017;24:5628-32. doi: 10.1007/ s11356-016-8198-4

2. Leal LS, Silva RLM, Aita KMSC, Monteiro RPA, Montalvão TC. Assessment of motor evelopment of children with congenital heart disease. Int. J Cardiov Scie 2016;29(2):1039. doi: $10.5935 / 2359-4802.20160017$

3. Silva P, Rocha R, Ferreira T. Perfil do óbito neonatal precoce decorrente do diagnóstico de cardiopatia congênita de um hospital universitário. Rev Enferm Cent Min 2013;3(3):83750. doi: 10.19175/recom.v0i0.409

4. Belo WA, Oselame GB, Neves EB. Perfil clínico-hospitalar de crianças com cardiopatia congênita. Cad. Saúde Colet 2016. doi: 10.1590/1414-462X201600020258

5. Araújo J, Régis C, Gomes R, Silva C, Abath, C, Mourato F, et al. Cardiopatia congênita no nordeste brasileiro: 10 anos consecutivos registrados no estado da Paraíba, Brasil. Rev Bras Cardiol 2014;27(1):13-9.

6. Zamith MM. Rastreamento das cardiopatias fetais: realidade em nosso meio. Rev Soc Cardiol Estado São Paulo 2011;21(4):43-8 doi: 10.1590/S0066-782X2004000400003

7. Pedra SRFF, Jatene MB, Pedra CAC, Ferrero C, Jatene LB, Tâmara C, et al. Importância da unidade fetal e serviço de cardiologia pediátrica integrados na mesma estrutura hospitalar Rev Soc Cardiol Estado de São Paulo 2011;21(4):49-53

8. Huber J, Peres VC, Santos TJ, Beltrão LF, Baumont AC, Cañedo $\mathrm{AD}$, et al. Cardiopatias congênitas em um serviço de referência: evolução clínica e doenças associadas. Arq Bras Cardiol 2010;94(3):333-8. doi: 10.1590/S0066782X2010000300009

9. Pérez ZR, López TCR, Rodríguez BA. Morbilidad y mortalidad del recién nacido prematuro en el Hospital General de Irapuato. Bol Med Hosp Infant Mex 2013;70(4):299-305. doi: S1665-11462013000400005

10. Atik E. Cardiopatias congênitas em Pediatria. Pediatr Mod 2011;47(4):116-26. doi: 10.15343/01047809.20174102144153

11. Bertoletti J, Marx GC, Hattge JSP, Pellanda LC. Qualidade de Vida e cardiopatia congenita na infancia e adolescencia. Arq Bras Cardiol 2014;102(2):192-8. doi: 10.5935/abc.20130244

12. Brasil. Ministério da Saúde. Secretaria de Atenção à Saúde. Departamento de Ações Programáticas e Estratégicas. Atenção à saúde do recém-nascido: guia para os profissionais de saúde. Brasília: MS; 2011.

13. Bixler GM, Powers GC, Clark RH, Walker MW, Tolia VN. Changes in the diagnosis and management of patent ductus arteriosus from 2006 to 2015 in united states neonatal intensive care units. J Pediatr 2017;189:105-12. doi: 10.1016/j.jpeds.2017.05.024.

14. Martin K. Ibuprofeno via oral e a persistência do canal arterial: uma nova abordagem para um problema antigo. J Pediatr 2013;89(1):4-5. doi: 10.1016/ j.jped.2013.02.002

15. Santos ADS, Menezes GA, Sousa DS. Perfil dos recémnascidos com cardiopatia congênita em uma maternidade de alto risco do município de Aracaju. Cad Grad Ciênc Biol Saúde 2013;1(17):59-70.

16. Rivera IR, Da Silva MA, Fernandes JM, Thomaz AC, Soriano CF, De Souza MG. Cardiopatia congênita no recém-nascido: da solicitação do pediatra à avaliação do cardiologista.
Arq Bras Cardiol 2007;89(1):6-10. doi: 10.1590/S0066782X2007001300002

17. Yang EM, Song ES, Choi YY. Comparison of oral ibuprofen and intravenous indomethacin for the treatmentof patent ductus arteriosus in extremely low birth weight infants. J Pediatr 2013;89:33-9. doi: j.jpedp.2012.08.003

18. Aranda JV, Thomas R. Systematic review: intravenous Ibuprofen in preterm newborns. Semin Perinatol 2006;30:11420.15. doi: $10.1053 /$ j.semperi.2006.04.003

19. Gimenez S, Teixeira ML, Myashiro R, Carmona MJC, Auler JJ, Malbouisson LMS. Avaliação pulmonar em crianças portadoras de cardiopatia congênita acianótica e hiperfluxo pulmonar através de tomografia computadorizada. Rev Bras Anestesiol 2009;59(5):545-57. doi: 10.1590/S003470942009000500003

20. Lanza FC, Barcellos PG, Corso S. Benefícios do decúbito ventral associado ao CPAP em recém-nascidos prematuros. Fisioter Pesq 2012;19(2):135-40. doi: 10.1590/S180929502012000200008.

21. Aragão JA, Mendonça MP, Silva MS, Moreira NA, Aragão ME, Reis FP. O perfil epidemiológico dos pacientes com cardiopatias congênitas submetidos à cirurgia no Hospital do Coração. Rev Bras Cienc Saúde 2013;17(3):263-8. doi: 10.4034/RBCS.2013.17.03.08

22. Cristovam MAS, Pavesi J, Bresolin AC, Câmara JPP, Plewka ACL, Seki HS, et al. Prevalência de desordens cardiológicas em uma UTI Neonatal. Rev Med Res 2013;15(4):272-82.

23. Tin W, Gupta S. Optimum oxygen therapy in preterm babies. Arch Dis Child Fetal Neonatal 2007;92:143-7. doi: 10.1136/ adc. 2005.092726

24. Sweet DG, Carnielli V, Greisen G, Hallman M, Ozek E, Plavka R, et al. European consensus guidelines on the management of respiratory distress syndrome - 2016 update. Neonatology 2017;111(2):107-25 doi:10.1159/000448985

25. Gomes PJ, Leina Z, Augusto B, Demarchi AV, Oliveira CV, Fernando CL et al. Tumores cardíacos em criança: análise retrospectiva. Arq Bras Cardiol 2013;100(2):120-6. doi: 10.5935/abc. 20130024

26. Oliveira PMN, De Held PA, Grande RA, Ribeiro MA, Bobbio TG, Schivinski CI. Perfil das crianças submetidas à correção de cardiopatia congênita e análise das complicações respiratórias. Rev Paul Pediatr 2012;30(1):116-21.

27. Pinto CP, Westphal F, Abrahão AR. Fatores de riscos materno associados à cardiopatia congênita. J Health Sci Inst 2018;36(1):34-08

28. Brasil. Ministério da Saúde. Secretaria de Atenção à Saúde. Departamento de Ações Programáticas Estratégicas. Gestação de alto risco: manual técnico. Brasília: MS; 2010.

29. Curzon CL, Milford-beland S, Li JS, O'brien SM, Jacobs JP, Welke KF, et al. Cardiac surgery in infants with low birth weight is associated with increased mortality: analysis of the Society of Thoracic Surgeons Congenital Heart Database. J Thorac Cardiovasc Surg 2008;135(3):546-51. doi:10.1016/j. jtcvs.2007.09.068.

30. Andrews RE, Simpson JM, Sharland GK, Sullivan ID, Yates RW. Outcome after preterm delivery of infants antenatally diagnosed with congenital heart disease. J Pediatr 2006;148(2):213-6. doi:10.1016/j.jpeds.2005.10.034 